\title{
A QUALITATIVE STUDY OF CUSTOMER SATISFACTION FROM AN ELECTRONIC COMMERCE PERSPECTIVE
}

\author{
Laurence Mukankusi, University of North Dakota, laurence.mukankusi@mail.business.und.edu \\ Fred Celimene, Universite des Antilles et de la Guyane, fred.celimene@martinique.univ-ag.fr \\ Louicius Michel, Canadian University College, Imichel@cauc.ca \\ Assion Lawson-Body, University of North Dakota, assion.lawsonbody@mail.business.und.edu
}

\begin{abstract}
The purpose of this study is to continue to fill a gap in the literature by investigating the impact of website-supported customer relationships on customer satisfaction. The study used content analysis to analyze the interview data obtained from a sample of 22 executives and webmasters of eight (8) IT companies in Quebec, Canada to test the hypotheses. The results show that three of the four website-supported customer relationships (partnerships, empowerment, and understanding customer expectations) have a positive impact on customer satisfaction. However, the impact of the website-supported trust on customer satisfaction is negative because the use of website-supported trust does not affect the level of customer satisfaction or dissatisfaction. That means, customers may be satisfied with the electronic relationships but they do not necessarily trust the company which used website support to build trust with its customers..
\end{abstract}

Keywords: Trust, Satisfaction, Website, Empowerment, Understanding Customer Expectations, Partnerships.

\section{INTRODUCTION}

Customer relationships have been conceptualized in terms of past interactions and the expectation of continued future interaction [14]. In others words, a relationship exists when an exchange is assessed not in isolation, but as a continuation of past exchanges likely to continue into the future [14]. These relationships are characterized by customer satisfaction as a desire for future interactions [14, 19]. A satisfied customer was viewed as an indispensable means of creating a sustainable advantage in the competitive environment of the 1990s [24, 21]. Existing models of customer satisfaction are based on the disconfirmation-ofexpectations paradigm [17, 21]. A new insight added to this paradigm concerns customer satisfaction formation, which refers to the process that a firm uses to monitor, diagnose, and take actions in maintaining relationships with its customers in order to optimize their satisfaction. The expectations of relationship continuity are based on the customer's satisfaction experience with the organization, which necessarily includes the effectiveness of the Internet's web tools supported the relationship in improving customer satisfaction.

Although researchers and stakeholders pay increasing attention to customer satisfaction and Internet website-supported customer relationships, not much is known about their interdependence. Also, the investigation of the role of satisfaction in the electronic commerce context is limited. Indeed, the use of the Internet's websites may have a direct impact on customer relationship or it may have a direct impact on customer satisfaction. However the simultaneous theoretical relationship among the use of the Internet's websites, customer relationships and customer satisfaction is not well examined.

The purpose of this study is to continue to fill a gap in the literature by investigating customer satisfaction as an electronic relationship phenomenon. In this article, we examine the impact of the websitesupported customer relationship on customer satisfaction. We believe that the nature and the effectiveness of the relationship a company has built with a customer could influence a customer's satisfaction. We extend the confirmation/disconfirmation paradigm of satisfaction by the use of websites-supported relationships as an alternative way to increase customer satisfaction.

This paper is organized as follows. Section II contains the description of customer satisfaction from an electronic commerce context. In Section III, the satisfaction theory is examined. In Section IV, the research model, the independent variables and hypotheses are presented. In Section V, the methodology is outlined. In Section VI, the results and findings are examined. In Section VII, the discussion of this paper is presented. In Section VIII, the conclusion is presented. 


\section{CUSTOMER SATISFACTION FROM AN ELECTRONIC COMMERCE CONTEXT}

Many recent studies have examined the Internet's web tools [31], and many researchers have written about the potential of Internet-based electronic commerce to alter customer relationships [28]. Less well understood, however, is how the use of the Internet's website-supported customer relationships affects customer satisfaction.

Customer satisfaction is prescribed to provide managers with the information to deploy the firm's Internet web tools to improve performance [20, 19, 21] because there is increasing evidence linking an organizational performance to the level of satisfaction reported by its customers. The resourcebased view theory states that investment in IT does not directly impact performance. There are some moderate variables such as customer relationships and satisfaction that need to be taken into account. In other words, investing in IT to strengthen customer relationships should lead to customer satisfaction, which in turn may positively impact performance.

Geissler et al., [12] used a combination of research methods (focus groups, interviews, and experiments) to identify web home page design elements that influence customers' perceptions of web page complexity. They found that perceived complexity is a result of four major factors: number of links, number of graphics, home page length, and animation. Also, they found evidence that web page complexity is related to communication effectiveness and partnerships as a precursor to customer satisfaction improvements.

After using the theory of modular design to explain the concept of web site services, Iyer et al., [16] have described how an emerging web site's services framework can be used to support dynamic business networks. Based on previous published work, they defined a business network as a distinct system of participants that use the network to achieve customer satisfaction and profitability and where relationships evolve over time.

By drawing on the theory of planned behavior and interpersonal influence, Song and Zahedi [27] developed and empirically tested a conceptual model for the process by which web site design elements could influence the purchase intentions of online customers. Eighmey and McCord (1998; cited in [31]) found that websites must give visitors a reason to return to the site. Research findings have revealed that the growth of on-line shopping is dependent on factors of vast selection, customer services, aftersales support and ease of contacting vendors. To maintain high customer satisfaction levels and thereby customer loyalty, firms are recommended to address these factors through different combinations of interactive functions that fit well into their website strategies and goals [26].

\section{THE CONCEPT OF SATISFACTION}

\section{The Confirmation/Disconfirmation Theory of Satisfaction}

The dominant theoretical model in the satisfaction literature is the disconfirmation of expectations paradigm $[24,19]$. This paradigm is widely accepted as a view of the process by which customers develop feelings of satisfaction or dissatisfaction [3, 19]. Actually, this paradigm posits that customer satisfaction is related to the size and direction of disconfirmation, which is defined as the difference between an individual's pre-purchase expectations (or some other comparison standard) and postpurchase performance of the product or service [24, 21]. In other words the disconfirmation construct is the perceived difference between what was received and what was expected [24, 21]. Future purchase behavior is a function of prior intention, attitude or expectations and this paradigm is linked to the evaluation ability of the customer. Because evaluation implies comparison of actual performance with some pre-defined standards, three outcomes of this evaluation are possible $[3,19]$. Confirmation occurs when performance matches the standard, leading to neutral feeling $[3,19]$. Performance better than the standard results in positive disconfirmation and, in turn, leads to satisfaction. Performance worse than the standard, creates negative disconfirmation and then dissatisfaction $[3,19]$.

\section{Extension of the Satisfaction Theory}

In the literature, many constructs were used to operationalize the theory of satisfaction such as norms, expectations, performance perceptions, disconfirmation, etc [19]. Other authors have extended this confirmation/disconfirmation theory of satisfaction because expectation is not the only standard customers use. Satisfaction has been explored as a multidimensional process.

A new model of satisfaction formation is proposed that extends the original disconfirmation of expectations theory by incorporating the processing of both chosen and non-chosen alternatives [10, 19]. After testing this model, the findings suggested that satisfaction with the non-chosen alternative remains salient in the determination of overall post-choice satisfaction $[10,19]$. It has been found that the non- 
choice alternatives may continue to be relevant in the satisfaction formation process $[10,19]$.

Many authors have given a new trend to the satisfaction theory. Anderson et al., [1] tested how satisfaction affects future customer behavior, and in turn, the level, timing, and risk of future cash flows. A positive association has been found between customer satisfaction and shareholder value [1]. Gruca and Rego [13] found that satisfaction creates shareholder value by increasing future cash flow growth and reducing its variability. Morgan et al., [20] studied a firm's customer satisfaction information usage and found that there are variations among the firms in the fieldwork and uncovered factors that may help explain the observed differences. Chandrashekaran et al., [5], after studying the satisfaction strength on customer loyalty, found that though satisfaction translates into loyalty when satisfaction is strongly held (low uncertainty), the translation is significantly lowered when the same satisfaction is more weakly held (high uncertainty). The studies also concluded that prior relationship aspects (length of relationship, volume of business, and favorability of prior experiences) results in even greater vulnerability [5]. Ofir and Simonson [21] examined alternative theoretical predictions about the impact of stating expectations before purchase on post-purchase perceptions of the shopping experience and the firm. They found that though pre-purchase expectations are indistinguishable from evaluations of the store's past performance, the former leads to lower post-purchase than pre-purchase evaluations, whereas the latter tends to generate higher post-purchase evaluations.

One of our goals in this study is to extend prior research by developing a conceptual model linking Internet's website-supported customer relationships to customer satisfaction.

\section{Satisfaction and Customer Relationships}

The concept of customer relationships has emerged, in part, because it values the relationship between the seller and the buyer. Customer relationships have been defined as a customer-centered approach whereby a firm seeks long-term business relations with existing customers [11]. A comprehensive model for customer relationships has been developed that includes input (understanding customer expectations, building partnerships, empowering employees, and total quality management), output (customer satisfaction, customer loyalty, product quality, and profitability) and assessment (customer feedback and integration). The model is applied to one industry: automated immunochemistry testing products. They found that the four relationship input factors do not have an equal impact on customer satisfaction, customer loyalty or product quality. Although respondents say the effects of building service partnerships, empowering employees, and total quality management are similar, understanding customer expectations does not have as significant of an effect.

\section{THE RESEARCH MODEL AND HYPOTHESES DEVELOPMENT}

The research model tries to demonstrate how the use of the Internet's websites can support the formation and maintenance of customer relationships because they facilitate the way organizations partner, understand customer expectations, empower, and trust each other in order to create satisfied customers.

In the research model shown in Figure 1, the dependent variable will be drawn from customer satisfaction. The independent variables will be drawn from the website-supported four interrelated relationship perspectives. Because these four interrelated relationship perspectives are supported by websites used by computer science or IT companies, they have been adapted as follows: website-supported partnerships, website-supported empowerment, website-supported understanding customer expectations and website-supported trust. Each of them is discussed below.

\section{Website-Supported Partnerships}

Partnerships are created when suppliers work closely with customers and add desired services to their traditional product and service offerings [11]. Companies engaging in website-supported partnerships employ multiple technologies to internally secure their Internet's web [4]. An assessment of the value of these technologies is crucial [4] for partners to satisfy each other.

Based on the application of incomplete contract theory, Subramani and Walden [29] found that the addition of new partners in the electronic commerce channel undermines existing relationships in the conventional channel; at the same time, existing relationships in the conventional channel undermine the quality of new relationships in the electronic commerce channel. They also found that, however, Internet firms, with their single channel focus, avoid this difficulty. Steinfield et al., [28] have examined the impact of the Internet on buyer-seller relationships. More specifically, they have examined whether the organizational data networks can have two opposing effects on buyer-seller relationships. On the one hand, networks may be used to foster 
electronic marketplaces characterized by more ephemeral transactions between buyers and sellers. Also plausible, however, is the use of networks to strengthen existing commercial relationships and lock in partners by increasing the costs of switching to new trading partners [28].

The navigational features of transactional web sites allow the partner easy access to information of interest, both internal and external to the site; they also provide the organization the ability to develop sections of the web site with restricted access, e.g. protected content available only to customers or partners by using a password [25]. Collectively, we hypothesize that:

H1: The website-supported partnerships will have a positive effect on customer satisfaction.

\section{Website-Supported Empowerment}

Empowerment is defined as the process firms adopt to encourage and reward employees who exercise initiative and make valuable creative contributions [11]. Firms that empower their employees to respond and listen to customer needs and requirements have satisfied customers, and develop strong relationships that lead to customer loyalty [11]. The company's web site protected by a secured firewall can be used to enhance the communication and collaboration among authorized employees. In fact, one study has claimed that companies often empower one or several employees to answer questions or to make comments online [9]. These actions are carried out by e-mail or through online discussion (online conferences, forums, or chat rooms) and allow companies and their customers to make the most of the online contact time provided by the Internet to share their views. Companies empower their employees who react online promptly to customer complaints [9].

Young and Benamati, [31] show that a majority of firms list their expertise on their web site, including such material as curriculum vitae, important references, and employees' accomplishments. Companies that take such steps empower their employees when they have to negotiate with external customers. This empowerment process has repercussions on the relationships which the employees initiate and maintain with their customers in order to satisfy them. Thus we propose the hypothesis below:

H2: The website-supported empowerment will have a positive effect on customer satisfaction.

\section{Website-Supported Understanding Customer Expectations}

Understanding customer expectations is defined as the strategy adopted by firms to generate more knowledge of customer expectations and needs and to provide customers with the best services [2]. Tagliavini et al., [30] found that web customer purchases are less than expected. In order to remedy disappointing commercial results on the web, they proposed, a better understanding of web customers is needed [2].

On-line collection of data and information about customer expectations reduces the social pressure associated with face-to-face discussion and increases attention to the task; this, in turn, should improve customer satisfaction [22]. With the use of the Internet's websites, it is possible to use forums, chat rooms, podcast, webex, and news groups in order to effectuate, for example, the focus group which should enable many companies to understand their customers' desires, needs and expectations [30]. Obviously, the companies which use the Internet websites should generate more knowledge of customer desires and expectations and provide customers with the best services so as to win their satisfaction. Indeed, customers want firms that are able to provide the best services corresponding to their expectations [23]; when firms do not provide those services to customers, these latter are not willing to commit to long term relationships with these firms. Therefore, a combination of sophisticated web sites and an effective strategy for understanding customer expectations should grow customer satisfaction. Some companies are integrating their customers' databases into their own web sites for understanding customer needs [6], so they can tie their customers' inventory and procurement systems to their systems. This will create better understanding of their customers' needs, requirements and expectations. Accordingly, it is hypothesized that:

H3: The website-supported understanding customer expectations will have a positive effect on customer satisfaction.

\section{Website-Supported Trust}

Trust is defined as the extent to which the customer believes that the vendor has intentions and motives that are beneficial to the customer [18]. Trust can be achieved by providing the customer with valuable information using a secure web site. Some authors speculate that in the early stages of Internet development, trust is a critical factor in stimulating relationships over the Internet [4] mainly because of 
security issues. Indeed, companies should use web content to try to promote their business partners' trust by publishing success stories and partner testimonials on their web sites or by carrying seals of approval by third parties, and so on. Since the attainment of customer satisfaction has customer trust as a prerequisite, electronic relationships supported by trust should lead to customer satisfaction. When customers trust an on-line partner, they will share and communicate strategic information; that electronic communication enables companies to form a more intimate relationship with customers, offering products and services tailored to their preferences, which in turn increases trust and strengthens satisfaction. Hence, we offer the hypothesis below:

H4: The website-supported trust will have a positive effect on customer satisfaction.

<insert Figure 1 here $>$

\section{METHODOLOGY: MULTIPLE CASE STUDIES}

This research focuses on IT company websites that are used to deliver services to their customers. The procedure used to process data was based on the guidelines suggested by Churchill [7]. In order to follow these guidelines, multiple case studies have been conducted. In total, twenty two management directors and webmasters of eight companies which belong to the IT sector in Quebec, Canada were asked to participate in the multiple case studies.

The interviews were held individually with each management director or/and webmaster for one hour. The interviews were tape-recorded, and the texts of the interviews were transcribed and entered into Microsoft Word software. To help conduct the interviews, an interview guide was used.

The study used content analysis to analyze the data obtained from a sample of management directors of IT companies to test the hypotheses. The common response was obtained by using the generalized answer from all management directors. The procedure for data analysis was based on totaling the overall counts of messages coded in each category and the analysis of the messages. Each research variable has played the role of category. Occurrences of the messages in each category have been analyzed to determine relative importance. Higher relative counts reflect the significance of the particular message within the specific category.

Chi-square is used as a statistical test in this paper because the data are in the form of raw frequency counts of things in two or more mutually exclusive and exhaustive categories [8]. In this study, we converted interview message frequencies into percentages. Any count of messages collected from the interview of the management directors and webmasters fall into only one category or value on each variable. For example, our data are counts of positive or negative messages expressing a preference for independent and dependent variables used in this study. Each message is counted only once. In other words, the interview contents have been transformed in quantitative data by counting the negative and positive messages about each category of our research design. The dependent variable (customer satisfaction) and the independent variables (the website-supported partnerships, the websitesupported empowerment, the website-supported understanding customer expectations, and the website-supported trust) have been used as categories. Since chi-square is similar to percentage, it extrapolates a population characteristic (a parameter) from the sampling characteristic (a statistic) similar to the way percentage standardizes a frequency to a total column $\mathrm{N}$ of 100 [8]. We converted the number of messages counted into percentages as if there were 100 messages in each category of the independent or dependent variable for comparability.

\section{RESULTS AND FINDINGS}

In this research, Chi-square, a non-parametric test of statistical significance for bivariate tabular analysis, was used to test the hypotheses and analyze data. The test of the hypotheses determined whether or not two different samples (of people or texts) are significantly different in some aspect of their behaviors. Then it can be generalized from the samples that the populations are also different in the behaviors [8].

\section{Hypothesis Testing (H1)}

Table 1 summarizes the number, percent, and chisquare of messages related to the impact of the website-supported partnerships on customer satisfaction.

\section{<insert Table 1 here $>$}

Table 1 presents the results of chi-square tests carried out to determine whether positive messages about the website-supported partnerships predominate over negative messages about the website-supported partnerships. The results show that positive messages were significantly greater than negative messages (68.22 at $\mathrm{p}<0.001$ ). Thus, Hypothesis 1, which states that website-supported partnerships will have a positive effect on customer satisfaction, is supported. 


\section{Hypothesis Testing (H2)}

Table 2 summarizes the number, percent, and chisquare of messages related to the impact of the website-supported empowerment on customer satisfaction.

\section{$<$ insert Table 2 here $>$}

Table 2 presents the results of chi-square tests carried out to determine whether positive messages about the website-supported empowerment predominate over negative messages about the website-supported empowerment. The results show that positive messages were significantly greater than negative messages (59.73 at $\mathrm{p}<0.001)$. Thus, Hypothesis 2, which states that website-supported empowerment will have a positive effect on customer satisfaction, is supported.

\section{Hypothesis Testing (H3)}

Table 3 summarizes the number, percent, and chisquare of messages related to the impact of the website-supported understanding customer expectations on customer satisfaction.

\section{$<$ insert Table 3 here $>$}

Table 3 presents the results of chi-square tests carried out to determine whether positive messages about the website-supported understanding customer expectations predominate over negative messages about the website-supported understanding customer expectations. The results show that positive messages were significantly greater than negative messages (77.24 at $\mathrm{p}<0.001$ ). Thus, Hypothesis 3 , which states website-supported understanding customer expectations will have a positive effect on customer satisfaction, is supported.

\section{Hypothesis Testing (H4)}

Table 4 summarizes the number, percent and chisquare of messages related to the impact of the website-supported trust on customer satisfaction.

\section{<insert Table 4 here $>$}

Table 4 presents the results of chi-square tests carried out to determine whether positive messages about the website-supported trust predominate over negative messages about the website-supported trust. The results show that negative messages were significantly greater than positive messages (48.64 at $\mathrm{p}<0.001$ ). Thus, Hypothesis 4, which states websitesupported trust will have a positive effect on customer satisfaction, is not supported.

\section{DISCUSSION}

Three of four hypotheses are supported. That means the four interrelated website-supported customer relationship factors do have different or unequal impact on customer satisfaction. The findings of the study support that there are connections between the use of websites to build customer relationships and satisfaction of IT companies' customers. The effect of website-supported partnerships, website-supported empowerment, website-supported understanding customer expectations on customer satisfaction is positive. However, the effect of website-supported trust on customer satisfaction is neutral. Also the use of a website positively affects the relationship between IT companies and their customers. If IT companies use websites to maintain relationships with customers, trust in IT companies may be positively affected, however customers will not necessarily be satisfied or dissatisfied accordingly. There are many explanations for this, which are discussed below.

Satisfaction is the result of a post-consumption or post-usage evaluation, containing both cognitive and affective elements $[15,19]$. The results of this study corroborates with this because IT companies build relationships with their customers after rending them services or signing maintenance contracts with them. The satisfaction IT customers develop will take into account the way those maintenance agreements will be managed or how IT companies, will execute their software, hardware or network implementation mandates. Usually, IT companies service delivery takes time because of the nature of their products and activities, during that time IT companies develop relationships with their customers because of the numerous interactions between both parties. Those interactions have a significant impact on the satisfaction formation process. By using the Internet's web tools to support relationships, IT companies should add another level of complexity to switching cost because this relationship should last and it will be costly to invest in new technologically maintained relationships with other suppliers. The new suppliers also should support the cost of new IT investment and implementation (training, etc).

According to the expectancy-disconfirmation paradigm, customers judge satisfaction by comparing previously held expectations with perceived product or service performance $[15,19]$. In addition, positive or negative affects which arise from the cognitive process of confirmation/disconfirmation, contributes to satisfaction or dissatisfaction [15]. Based on the findings of this study, customers do not judge their 
level of trust in the IT companies when it's time to compare what was received to what was expected.

\section{CONCLUSIONS}

The main contribution of this study is the extension of the model of satisfaction by incorporating websitesupported customer relationships that begin with partnerships, empowerment, understanding customer expectations, and trust. We then extended the model to incorporate another antecedent to customer satisfaction. Also, this study has provided empirical evidence on the effect of the use of websites on the relationship between partnerships, empowerment, understanding customer expectations, and trust and customer satisfaction.

The author encourages practitioners and researchers to use the findings of this study for various electronic commerce applications.

There are two limitations of this study. First, it focuses on only one industry (IT companies) and it remains to be seen if the results apply to other industries (e.g. Automobile and Transportation, Hotels, and Airline Industry). Second, there were limitations concerning the interviews used particularly in regards to the profile of respondents. Certain statements indicated that some respondents were managers or webmasters who did not necessarily have an adequate knowledge of their organizations.

\section{REFERENCES}

1. Anderson, E. W., Fornell, C. \& Mazvancheryl, S. K. (2004). Customer Satisfaction and Shareholder Value. Journal of Marketing, Vol. 68, October, pp. 172-185.

2. Burton, M. and J. B. Walther (2001), "The value of Web log data in use-based design and testing”, Journal of Computer-Mediated Communication [On-line], (3)6, Available: http://www.ascusc.org/jcmc/vol6/issue3/burton.h $\underline{\mathrm{tml}}$

3. Cadotte, E. R., Woodruff, R. B. \& Jenkins, R. L. (1987). Expectations and Norms in Models of Consumer Satisfaction. Journal of Marketing Research, Aug, pp. 305-314.

4. Cavusoglu, H., Raghunathan, S. \& Mishra, B. (2002) Optimal design of information technology security architecture, Twenty-Third ICIS, pp. 749-756.

5. Chandrashekaran, M., Rotte, K., Tax, S. S. \& Grewal, R. (2007). Satisfaction Strength and Customer Loyalty. Journal of Marketing Research, Vol. XLIV, Feb, pp. 153-163.
6. Chatterjee, D., R. Grewal and V. Sambamurthy (2002) "Shaping up for E-commerce: Institutional enablers of the organizational assimilation of web technologies”, MIS Quarterly, (26)2, pp. 65-89.

7. Churchill, G. A. (1979) A Paradigm for developing better measures of marketing constructs. Journal of Marketing Research, 16(1), 64-73.

8. Connor-Linton, J. (2003) Chi-Square Tutorial. Retrieved June 20 $0^{\text {th }}$, 2005 from http://www.georgetown.edu/faculty/ballc/webtoo ls/web_chi tut.html

9. Dholakia U. M. and Rego, L. (1998). What makes commercial Web pages popular? An empirical investigation of Web page effectiveness, European Journal of Marketing, (32)7/8, pp. 724-736.

10. Droge, C., Halstead, D. \& Mackoy, R. D. (1997). The Role of Competitive Alternatives in the Postchoice Satisfaction Formation Process. Journal of the Academy of Marketing Science, Vol. 25, No. 1, pp. 18-30.

11. Evans, J. R. and R. L. Laskin (1994) "The Relationship Marketing Process : A Conceptualization and Application”, Industrial Marketing Management, (23)5, pp. 439-452.

12. Geissler, G. G. Zinkhan, and R. T. Watson (2001) "Web Home page complexity and Communication Effectiveness", Journal of the Association for Information Systems, (2)2, pp. 148.

13. Gruca, T. S. \& Rego, L. L. (2005). Customer Satisfaction, Cash Flow, and Shareholder Value. Journal of Marketing, Vol. 69, July, pp. 115-130.

14. Hess, R. L., Ganesan, S., \& Klein, N. M. (2003). Service Failure and Recovery: The Impact of Relationship Factors on Customer Satisfaction. Journal of the Academy of Marketing Science, Vol. 31, No. 2, pp. 127-145.

15. Homburg, C., Koschate, N., \& Hoyer, W. D. (2005). Do Satisfied Customers Really Pay More? A Study of the Relationship Between Customer Satisfaction and Willingness to Pay. Journal of Marketing, Vol. 69, April, pp. 84-96.

16. Iyer B., J. Freedman, M. Gaynor and G. Wyner (2003) "Web services: enabling dynamic business networks", Communications of the Association for Information Systems, (11), pp. 525-555.

17. Lam, S. Y., Shankar, V., Erramilli, \& Murthy, B. (2004) Customer Value, Satisfaction, Loyalty, and Switching Costs: An illustration From a Business-to-Business Service Context. Journal of the Academy of Marketing Science, Vol. 32, No. 3, pp. 293-311.

18. Lewin, J. E. and W. J. Johnston (1997). "Relationship Marketing Theory in Practice: A 
Case Study,” Journal of Business Research, 39, 23-31.

19. Luo, X. \& Homburg C. (2007). Neglected Outcomes of Customer Satisfaction. Journal of Marketing. 71(4), 133-149.

20. Morgan, N. A., Anderson, E. W., Mittal, V. (2005). Understanding Firms' Customer Satisfaction Information Usage. Journal of Marketing, Vol. 69, July, pp. 131-151.

21. Ofir, C. \& Simonson, I. (2007). The Effect of Stating Expectations on Customer Satisfaction and Shopping Experience. Journal of Marketing Research Vol. XLIV, Feb, pp. 164-174.

22. Ozer, M. (2000) "Information Technology and New Product Development", Industrial Marketing Management, 29(5), pp. 387-396.

23. Parasuraman, A., L. L. Berry and V. A. Zeithaml (1991) "Understanding Customer Expectations of Service”, Sloan Management Review, (32)3, pp. 39-48.

24. Patterson, P. G., Johnson, L. W. \& Spreng, R. A. (1997). Modeling the Determinants of Customer Satisfaction for Business-toBusiness Professional Services. Journal of the Academy of Marketing Science, Vol. 25, No. 1, pp. 4-17.

25. Robbins, S. S. and Stylianou, C. A. (2003). Global corporate web sites: an empirical investigation of content and design, Information and Management, (40)3, pp. 205-212

26. Shim, J. P., Y. B. Shin and L. Nottingham (2002) "Retailer Web Site Influence on Customer Shopping: An Exploratory Study on Key Factors of Customer Satisfaction”, Journal of the Association for Information Systems, (3), pp. 5376.

27. Song, J. and F. M. Zahedi (2001). Web design in e-commerce: a theory and empirical analysis, Twenty-Second International Conference on Information Systems, pp. 205-219.

28. Steinfield, C., A. Chan and R. E. Kraut (2000). Computer mediated markets: An introduction and preliminary test of market structure impacts, Journal of Computer-Mediated Communication [On-line], (3)5, Available: http://www.ascusc.org/jcmc/vol5/issue3/steinfiel d.html

29. Subramani M. and Walden, E. (2000), Economic returns to firms from business-to-business electronic commerce initiatives: an empirical examination, Twenty-One International Conference on Information Systems, pp. 229241

30. Tagliavini, M., A, Ravarini and A. Antonelli (2001) "An evaluation model for electronic commerce activities within SMEs”, Information Technology and Management, 2, pp. 211-230.

31. Young, D. and J. Benamati (2000) "Differences in Public Web Sites: The Current State of Large
U.S. Firms," Journal of Electronic Commerce Research, 1(3), pp. 1-19.

\section{APPENDIX}

$<$ insert Table 5 here $>$

<insert Table 6 here>

<insert Table 7 here $>$

<insert Table 8 here> 


\section{TABLES AND FIGURES}

Figure 1. Theoretical Research model

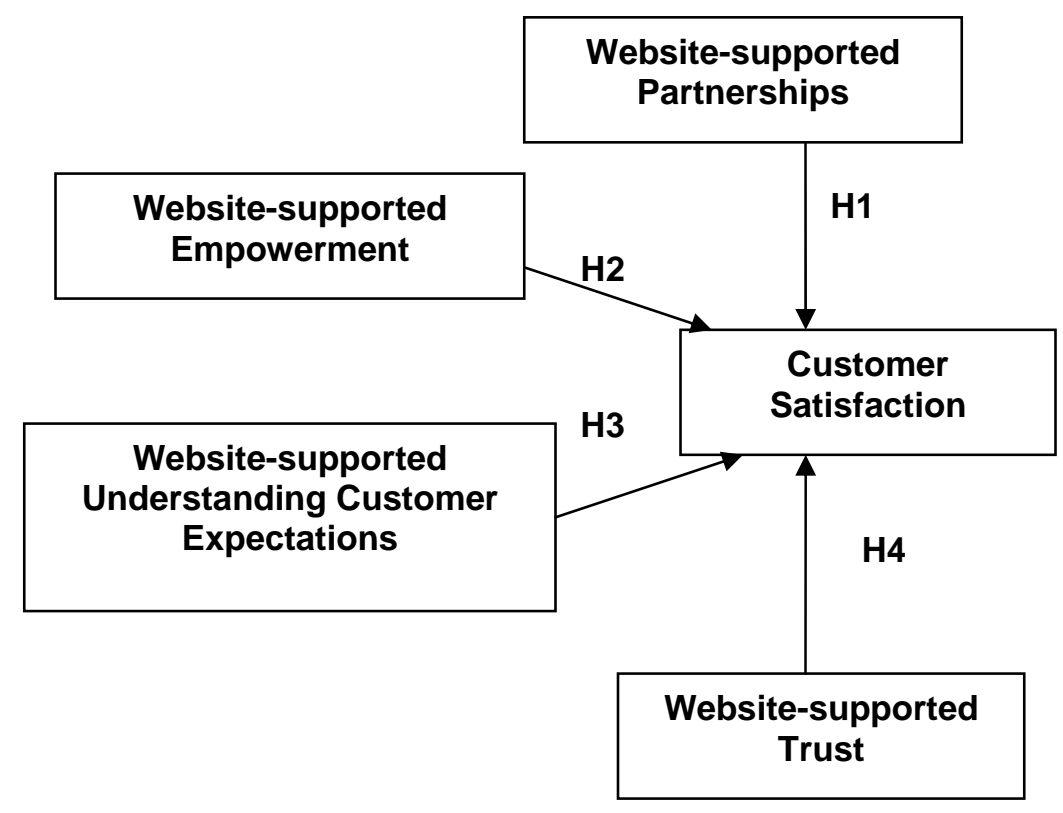

Table 1. Number, Percent, and Chi-square of website-supported partnerships

\begin{tabular}{|c|c|c|c|c|}
\hline $\begin{array}{l}\text { Coded } \\
\text { Messages }\end{array}$ & Number & $\begin{array}{c}\text { Percentage } \\
\text { (\%) }\end{array}$ & $\begin{array}{l}\text { Number of } \\
\text { respondents }\end{array}$ & $\begin{array}{c}\text { Chi- } \\
\text { Square }\end{array}$ \\
\hline PCP & 28 & 85 & 15 & \multirow[t]{3}{*}{$16.03^{* * *}$} \\
\hline$\overline{\mathrm{PCPN}}$ & 5 & 15 & 7 & \\
\hline Total & 33 & 100 & 22 & \\
\hline RSP & 34 & 77 & 18 & \multirow{3}{*}{$13.09^{* *}$} \\
\hline RSPN & 10 & 23 & 4 & \\
\hline Total & 44 & 100 & 22 & \\
\hline$\overline{\mathrm{DCP}}$ & 23 & 74 & 17 & \multirow{3}{*}{7.25} \\
\hline DCPN & 8 & 26 & 5 & \\
\hline Total & 31 & 100 & 22 & \\
\hline ССР & 39 & 75 & 16 & \multirow[t]{3}{*}{$13.00^{* *}$} \\
\hline CCPN & 13 & 25 & 6 & \\
\hline Total & 52 & 100 & 22 & \\
\hline & & & & \multirow{4}{*}{$8.10 *$} \\
\hline RPP & 29 & 72.5 & 13 & \\
\hline RPPN & 11 & 27.5 & 9 & \\
\hline Total & 40 & 100 & 22 & \\
\hline GBP & 31 & 76 & 14 & \multirow[t]{2}{*}{$10.75^{*}$} \\
\hline GBPN & 10 & 24 & 8 & \\
\hline
\end{tabular}




\begin{tabular}{|l|c|c|c|c|}
\hline Total & 41 & 100 & 22 & \\
\hline \multicolumn{4}{|c|}{ The total chi-square value for Table 1 is } & $68.22^{* * *}$ \\
\hline
\end{tabular}
$* * * \mathrm{P}<0.001 ;{ }^{* *} \mathrm{p}<0.025 ;{ }^{*} \mathrm{p}<0.05$

Table 2. Number, Percent, and Chi-square of website-supported empowerment

\begin{tabular}{|c|c|c|c|c|}
\hline $\begin{array}{l}\text { Coded } \\
\text { Messages }\end{array}$ & Number & $\begin{array}{c}\text { Percentage } \\
(\%)\end{array}$ & $\begin{array}{c}\text { Number } \\
\text { of } \\
\text { IT firms } \\
\end{array}$ & $\begin{array}{c}\text { Chi- } \\
\text { Square }\end{array}$ \\
\hline REE & 34 & 72 & 16 & \multirow[t]{3}{*}{ 9.38* } \\
\hline REEN & 13 & 28 & 6 & \\
\hline Total & 47 & 100 & 22 & \\
\hline PEE & 41 & 84 & 17 & \multirow[t]{3}{*}{$22.22 * * *$} \\
\hline PEEN & 8 & 16 & 5 & \\
\hline Total & 49 & 100 & 22 & \\
\hline TME & 33 & 79 & 16 & \multirow[t]{3}{*}{$13.71^{* *}$} \\
\hline TMEN & 9 & 21 & 6 & \\
\hline Total & 42 & 100 & 22 & \\
\hline TTE & 27 & 67.5 & 14 & \multirow[t]{3}{*}{4.9} \\
\hline TTEN & 13 & 32.5 & 8 & \\
\hline Total & 40 & 100 & 22 & \\
\hline EEE & 31 & 74 & 15 & \multirow[t]{3}{*}{$9.52 *$} \\
\hline EEEN & 11 & 26 & 7 & \\
\hline Total & 42 & 100 & 22 & \\
\hline \multicolumn{4}{|c|}{ The total chi-square value for Table 2 is } & $59.73 * * *$ \\
\hline
\end{tabular}

Table 3. Number, Percent, and Chi-square of website-supported understanding customer expectations

\begin{tabular}{|c|c|c|c|c|}
\hline $\begin{array}{l}\text { Coded } \\
\text { Messages }\end{array}$ & Number & $\begin{array}{c}\text { Percentage } \\
(\%)\end{array}$ & $\begin{array}{l}\text { Number } \\
\text { of IT firms }\end{array}$ & Chi-Square \\
\hline PCS & 28 & 74 & 16 & \multirow[t]{3}{*}{$8.52 *$} \\
\hline PCSN & 10 & 26 & 6 & \\
\hline Total & 38 & 100 & 22 & \\
\hline DII & 35 & 78 & 17 & \multirow[t]{3}{*}{$13.88 * *$} \\
\hline DIIN & 10 & 22 & 5 & \\
\hline Total & 45 & 100 & 22 & \\
\hline PFH & 33 & 72 & 15 & \multirow[t]{3}{*}{$8.69 *$} \\
\hline PFHN & 13 & 28 & 7 & \\
\hline Total & 46 & 100 & 22 & \\
\hline OFC & 41 & 72 & 16 & \multirow[t]{3}{*}{ 10.96* } \\
\hline OFCN & 16 & 28 & 6 & \\
\hline Total & 57 & 100 & 22 & \\
\hline SCS & 38 & 81 & 17 & \multirow[t]{3}{*}{$17.89 * * *$} \\
\hline SCSN & 9 & 19 & 5 & \\
\hline Total & 47 & 100 & 22 & \\
\hline
\end{tabular}




\begin{tabular}{|l|c|c|c|c|}
\hline UCE & 41 & 79 & 15 & \multirow{2}{*}{$17.30 * * *$} \\
\cline { 1 - 2 } UCEN & 11 & 21 & 7 & \\
\hline Total & 52 & 100 & 22 & \multirow{2}{*}{$77.24 * * *$} \\
\hline \multicolumn{4}{|r}{ The total chi-square value for Table 3 is } & \\
\hline
\end{tabular}

Table 4. Number, Percent, and Chi-square of website-supported trust

\begin{tabular}{|c|c|c|c|c|}
\hline $\begin{array}{l}\text { Coded } \\
\text { Messages }\end{array}$ & Number & $\begin{array}{c}\text { Percentage } \\
(\%)\end{array}$ & $\begin{array}{c}\text { Number } \\
\text { of IT } \\
\text { firms }\end{array}$ & $\begin{array}{c}\text { Chi- } \\
\text { Square }\end{array}$ \\
\hline BLI & 7 & 19 & 9 & \multirow[t]{3}{*}{$14.29 * *$} \\
\hline BLIN & 30 & 81 & 13 & \\
\hline Total & 37 & 100 & 22 & \\
\hline PRM & 14 & 25 & 8 & \multirow[t]{3}{*}{$14.00 * *$} \\
\hline PRMN & 42 & 75 & 14 & \\
\hline Total & 56 & 100 & 22 & \\
\hline $\mathrm{CBH}$ & 23 & 53 & 11 & \multirow[t]{3}{*}{0.20} \\
\hline CBHN & 20 & 47 & 11 & \\
\hline Total & 43 & 100 & 22 & \\
\hline DCA & 11 & 24 & 6 & \multirow[t]{3}{*}{$11.75^{*}$} \\
\hline DCAN & 34 & 76 & 16 & \\
\hline Total & 45 & 100 & 22 & \\
\hline $\mathrm{CCT}$ & 16 & 36 & 7 & \multirow[t]{3}{*}{3.75} \\
\hline CCTN & 29 & 64 & 15 & \\
\hline Total & 45 & 100 & 22 & \\
\hline CCR & 9 & 34 & 8 & \multirow[t]{3}{*}{3.57} \\
\hline CCRN & 19 & 66 & 12 & \\
\hline Total & 28 & 100 & 20 & \\
\hline $\mathrm{CHI}$ & 19 & 42 & 7 & \multirow[t]{3}{*}{1.08} \\
\hline $\mathrm{CHIN}$ & 26 & 58 & 15 & \\
\hline Total & 45 & 100 & 20 & \\
\hline \multicolumn{4}{|c|}{ The total chi-square value for Table 4 is } & $48.64 * * *$ \\
\hline
\end{tabular}

Table 5. Website-Supported Partnerships

\begin{tabular}{|l|l|l|}
\hline $\begin{array}{l}\text { Negative } \\
\text { Coded } \\
\text { Messages }\end{array}$ & $\begin{array}{l}\text { Positive } \\
\text { Coded } \\
\text { Messages }\end{array}$ \\
\hline PCPN & PCP & Joint advertising programs with customers. \\
\hline RSPN & RSP & Resale of your firm's products and services by your customers. \\
\hline DCPN & DCP & Joint development of products and services with customers. \\
\hline CCPN & CCP & Creation of joint ventures with customers. \\
\hline RPPN & RPP & $\begin{array}{l}\text { Reference to your firm's products and services when customers sell their own products and } \\
\text { services. }\end{array}$ \\
\hline GBPN & GBP & In general, your firm builds partnerships with its customers.
\end{tabular}


Table 6. Website-supported Empowerment

\begin{tabular}{|l|l|l|}
\hline $\begin{array}{l}\text { Negative } \\
\text { Coded } \\
\text { Messages }\end{array}$ & $\begin{array}{l}\text { Positive } \\
\text { Coded } \\
\text { Messages }\end{array}$ \\
\hline REEN & REE & Your firm rewards employees who do their very best to solve customer problems. \\
\hline PEEN & PEE & $\begin{array}{l}\text { Your firm has policies indicating to employees their degree of responsibility and authority in } \\
\text { solving customer problems. }\end{array}$ \\
\hline TMEN & TME & Your firm has a relationship training program for technical service employees. \\
\hline TTEN & TTE & $\begin{array}{l}\text { Your firm has a technical training program for customer service personnel and customer } \\
\text { representatives. }\end{array}$ \\
\hline EEEN & EEE & In general, your firm empowers employees with regards to customer relations.
\end{tabular}

Table 7. Website-supported Understanding Customer Expectations

\begin{tabular}{|l|l|l|}
\hline $\begin{array}{l}\text { Negative } \\
\text { Coded } \\
\text { Messages }\end{array}$ & $\begin{array}{l}\text { Positive } \\
\text { Coded } \\
\text { Messages }\end{array}$ & \\
\hline PCSN & PCS & Your firm provides the personalized customer support to each customer \\
\hline DIIN & DII & The customer can consult data and information about your firm's portfolio via the web site \\
\hline PFHN & PFH & Your firm provides a form to chat with its customers \\
\hline OFCN & OFC & Your firm organizes focus group with its customers \\
\hline SCSN & SCS & Your firm does survey to collect data about its customer satisfaction \\
\hline UCEN & UCE & In general, your firm understand its customer expectations \\
\hline
\end{tabular}

Table 8. Website-supported Trust

\begin{tabular}{|l|l|l|}
\hline $\begin{array}{l}\text { Negative } \\
\text { Coded } \\
\text { Messages }\end{array}$ & $\begin{array}{l}\text { Positive } \\
\text { Coded } \\
\text { Messages }\end{array}$ & \\
\hline BLIN & BLI & Your firm can't be trusted, it's just too busy looking out itself \\
\hline PRMN & PRM & Your firm can be relied on to keep the promises that it makes \\
\hline CBHN & CBH & Your firm is basically honest \\
\hline DCAN & DCA & Despite what your firm says, it will try to take advantage of its customers \\
\hline CCTN & CCT & Your firm cannot be trusted at times \\
\hline CCRN & CCR & Your firm can be counted on to do what is right \\
\hline CHIN & CHI & In general, your firm has high integrity \\
\hline
\end{tabular}

